\title{
Article \\ Effects of Two Months of Very Low Carbohydrate Ketogenic Diet on Body Composition, Muscle Strength, Muscle Area, and Blood Parameters in Competitive Natural Body Builders
}

\author{
Antonio Paoli ${ }^{1,2}{ }^{\oplus}$, Lorenzo Cenci ${ }^{3}$, PierLuigi Pompei ${ }^{4}$, Nese Sahin ${ }^{5}$, Antonino Bianco ${ }^{6}$, Marco Neri ${ }^{7}$, \\ Massimiliano Caprio ${ }^{7,8}$ and Tatiana Moro ${ }^{1, * \text { D }}$ \\ 1 Department of Biomedical Sciences, University of Padua, 35131 Padua, Italy; antonio.paoli@unipd.it \\ 2 Research Center for High Performance Sport, UCAM, Catholic University of Murcia, 30107 Murcia, Spain \\ 3 Brain, Mind and Computer Science Doctoral Program, University of Padua, 35131 Padua, Italy; \\ lorenzo.cenci@studenti.unipd.it \\ 4 Unit of Pharmacology, School of Pharmacy, University of Camerino, 62032 Camerino, Italy; \\ pete.pompei@unicam.it \\ 5 Faculty of Sport Science, Ankara University, 06830 Ankara, Turkey; nesesahin@ankara.edu.tr \\ 6 Department of Psychology, Educational Science and Human Movement, Sport and Exercise Sciences Research \\ Unit, University of Palermo, 90128 Palermo, Italy; antonino.bianco@unipa.it \\ 7 Department of Human Sciences and Promotion of the Quality of Life, San Raffaele Roma Open University, \\ 00166 Rome, Italy; neri@cervia.com (M.N.); massimiliano.caprio@uniroma5.it (M.C.) \\ 8 Laboratory of Cardiovascular Endocrinology, IRCCS San Raffaele Pisana, 00163 Rome, Italy \\ * Correspondence: tatiana.moro@unipd.it; Tel.: +39-049-827-5306
}

check for updates

Citation: Paoli, A.; Cenci, L.; Pompei, P.; Sahin, N.; Bianco, A.; Neri, M.; Caprio, M.; Moro, T. Effects of Two Months of Very Low Carbohydrate Ketogenic Diet on Body Composition, Muscle Strength, Muscle Area, and Blood Parameters in Competitive Natural Body Builders. Nutrients 2021, 13, 374. https://doi.org/ $10.3390 /$ nu13020374

Academic Editor: Fernando Naclerio Received: 24 December 2020

Accepted: 22 January 2021

Published: 26 January 2021

Publisher's Note: MDPI stays neutral with regard to jurisdictional claims in published maps and institutional affiliations.

Copyright: (c) 2021 by the authors. Licensee MDPI, Basel, Switzerland. This article is an open access article distributed under the terms and conditions of the Creative Commons Attribution (CC BY) license (https:// creativecommons.org/licenses/by/ $4.0 /)$.
Abstract: Background: Ketogenic diet (KD) is a nutritional approach that restricts daily carbohydrates, replacing most of the reduced energy with fat, while maintaining an adequate quantity of protein. Despite the widespread use of KD in weight loss in athletes, there are still many concerns about its use in sports requiring muscle mass accrual. Thus, the present study sought to investigate the influence of a KD in competitive natural body builders. Methods: Nineteen volunteers $(27.4 \pm 10.5$ years) were randomly assigned to ketogenic diet (KD) or to a western diet (WD). Body composition, muscle strength and basal metabolic rate were measured before and after two months of intervention. Standard blood biochemistry, testosterone, IGF-1, brain-derived neurotrophic factor (BDNF) and inflammatory cytokines (IL6, IL1 $\beta, \mathrm{TNF} \alpha$ ) were also measured. Results: Body fat significantly decreased in KD ( $p=0.030)$; whilst lean mass increased significantly only in $\operatorname{WD}(p<0.001)$. Maximal strength increased similarly in both groups. KD showed a significant decrease of blood triglycerides $(p<0.001)$, glucose $(p=0.001)$, insulin $(p<0.001)$ and inflammatory cytokines compared to WD whilst BDNF increased in both groups with significant greater changes in KD $(p<0.001)$. Conclusions: KD may be used during body building preparation for health and leaning purposes but with the caution that hypertrophic muscle response could be blunted.

Keywords: ketogenic diet; strength; resistance training; health

\section{Introduction}

Ketogenic diet (KD) is a nutritional approach based on a reduced intake of carbohydrates (less than 20/30 g per day or 5\% of total energy) [1-3], a high fat content and an adequate level of proteins, the latter generally close to or slightly higher than the Italian recommended daily intake (LARNs recommendation) of $0.9 \mathrm{~g}$ per $\mathrm{kg}$ of body weight [4]. The metabolic advantage induced by KD is represented by the drastic reduction in carbohydrates, which force the body to primarily use fat as a fuel source as demonstrated by the decrease of the respiratory exchange ratio (RER) $[5,6]$.

Glucose is a fundamental energy source for the central nervous system, which is protected by the blood-brain barrier not allowing the passage of free fatty acids. After 
a few days of $\mathrm{KD}$, there is a drop in glucose availability due to reduced glycogen stores and thus an alternative energy source is required $[7,8]$. This energy is supplied by ketone bodies (KBs): acetoacetate (AcAc), 3-hydroxybutyrate (BHB) and acetone. KBs are generated through a process called ketogenesis from acetyl-CoA that occurs mainly in the mitochondrial matrix of the liver. Although created in the liver, this organ is unable to utilize KB due to a lack of the succinyl-CoA: 3-CoA transferase enzyme, which is required to convert acetoacetate to aceto-acetyl-CoA. $\mathrm{KBs}$ are thus released into the extrahepatic bloodstream and can be used by other tissues as energy source, by converting BHB into acetoacetate and then into aceto-acetyl-CoA, which can be further transformed into two acetyl-CoA molecules and enter the Krebs cycle [9]. At the end of this process, the energy produced from KBs is greater compared with glucose [2,10]. Initially, the necessary amount of acetyl-CoA is supplied by hepatic glycogenolysis and gluconeogenesis, but after fourseven days of KD, lipolysis of adipose tissue becomes the main source. In the long term, this adaptation translates into a reduction in the respiratory ratio which represents the metabolic switch towards a greater reliance on fatty acids [6,11].

KD is a well-proven approach to promote weight loss [2], and it has recently been used as a valuable therapeutic option to treat metabolic disorders, cardiovascular disease and type 2 diabetes [12]. Its role in sport performance is still controversial, with some authors experiencing favorable effects $[3,13]$ whilst other discourage the use of such dietetic approach, at least in endurance sports [14-16]. For athletes who compete in weight-category sports, KD could be a safe weight loss method, not compromising performance, therefore it may represent a legitimate and important tool for athletes. Paoli et al., for instance, demonstrated that 30 days of KD decreased body weight and body fat without negative effects on strength in high level gymnasts [13]. However, it might seem counterproductive for those athletes who seek maximum muscle hypertrophy [17], as several studies have shown no accretion of muscle mass during the ketosis phase [13,18-20]. Despite this, numerous bodybuilders use KD without a justified reason; however, no studies have yet explored its role in this particular sport category [21-23]. Professional bodybuilders' goals are to keep a perfect balance between muscle size and body fat, in order to obtain the most accurate symmetry and muscular proportion. To achieve their objectives, bodybuilders undergo a cycle of different training intensities in combination with various dietetic regimen in order to increase muscle mass during the "off-season" and reduce fat mass during competition preparation [21]. In this context, KD seems to be a useful diet to reduce fat mass, but its role in preserving athletic performance and muscle hypertrophy in physique athletes is still poorly investigated.

The high intensity and frequency of training employed by bodybuilders during their contest preparation may also induce muscle damage [24-26], which could ultimately result in a chronic inflammatory status, with increased level of IL-6, IL-1 and TNF- $\alpha$ [27]. On the other hand, a weight loss program can increase stress, anxiety and negatively affect athlete's mood [28]. The brain-derived neurotrophic factor (BDNF) is a protein associated with major depressive disorders and stress situations $[29,30]$. It has been shown that KD may have positive effects on inflammation [31-33] and can reduce depression-like behaviors [34] in both animals and human models, but no data are available about its effect on athletes such as bodybuilders.

The aim of the present study is to evaluate the effects of the ketogenic diet on body composition, muscle mass, strength and some blood parameters mainly related to lipid profile, hormonal (i.e., IGF-1) and inflammatory status (i.e., IL-6, TNF $\alpha$ and IL-1 $\beta$ ) in competitive body building athletes. Basal metabolism and respiratory quotient were also assessed in order to monitor the metabolic adaptation to KD.

\section{Materials and Methods}

This study is a randomized controlled parallel study (Figure 1). After signing the informed consent, the participants were invited to refer to the Exercise Nutrition and Physiology laboratory of the Department of Biomedical Sciences of the University of 
Padova. During the first visit, the participants underwent a medical screening to ensure eligibility for the study and a food interview to gather information on the participants' dietary habits. Subjects were examined after overnight fasting for blood sample collection, followed by body composition measurements via bioimpedance analysis (BIA) and basal metabolic rate assessment via indirect calorimetry. In a second visit, participants underwent maximal strength tests (1-RM) for bench press and squat exercises. During the second visit, all subjects received a personalized diet protocol, to be followed for eight weeks; adherence to the dietary regimen and ketonemia were monitored weekly through a portable device. Weekly results of blood BHB were sent to the research team: a value under $0.5 \mathrm{mmol} / \mathrm{L}$ was selected as non-adherence index and used to exclude subjects from the analysis. All participants maintained BHB levels over the defined limit and were included in the final analysis. Participants kept their own training routine, which was personalized and different for all participants. Athletes took part in the study in a period away from the competition phase: workouts had a daily schedule and were divided by muscle groups, and training sessions included exercises mainly aimed at increasing strength and muscle mass. After eight weeks subjects repeated the strength tests and body composition analysis and basal metabolism were reassessed $72 \mathrm{~h}$ after the last workout blood sampling

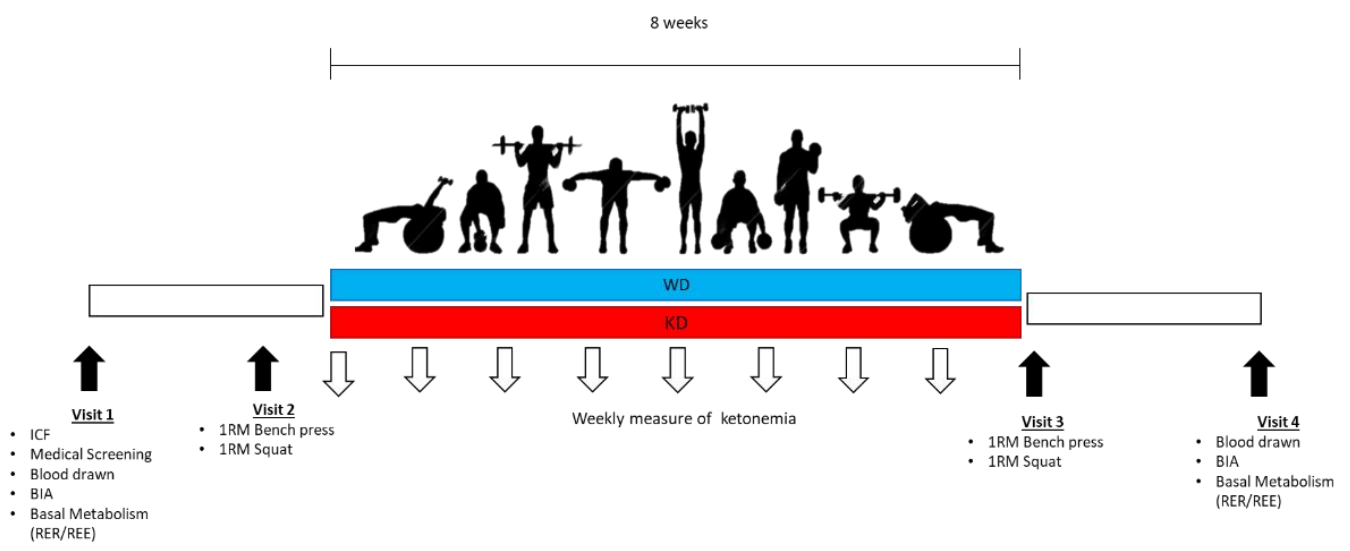

Figure 1. Study design. ICF, Informed consent form signed; BIA, Bioelectrical Impendence Analysis; REE, Basal metabolism; RER, respiratory quotient; 1 RM, 1 repetition-maximum test; WD, Western diet, KD, Ketogenic Diet.

\subsection{Subjects}

Nineteen male athletes (age $27.42 \pm 10.54$ years; BMI $26.80 \pm 1.91 \mathrm{~kg} / \mathrm{m}^{2}$; lean mass $88.62 \pm 2.81 \%$ ) were recruited from the sports centers of Emilia-Romagna and Veneto through advertising direct to coaches. Subjects aged between 20 and 40 years old were included in the study if they had at least five years of training experience and were competing in a recognized body building category. Exclusion criteria were use of steroids, chronic use of any medication, metabolic disorders or any other clinical problems that could be aggravated by the study procedures. Use of steroids was excluded by coaches' interview, and as athletes had officially enrolled in natural body building categories. Table 1 shows the anthropometric characteristics at baseline. Before any procedures, all participants signed the informed consent for data collection approved by the ethical committee of the Department of Biomedical Sciences, University of Padova (HEC-DSB 11/19), according to the current Declaration of Helsinki. At the end of the first screening, subjects were randomly assigned to these experimental groups: ketogenic diet $(\mathrm{KD} ; n=9)$ or control western diet (WD; $n=10$ ). The study was retrospectively registered at clinical trials.gov as NCT04629365. 
Table 1. Baseline characteristics of Ketogenic Diet (KD) and control western diet (WD) groups.

\begin{tabular}{cccc}
\hline & KD $(\boldsymbol{n}=\mathbf{9})$ & WD $(\boldsymbol{n}=\mathbf{1 0})$ & $\boldsymbol{p}$-Value \\
\hline Age $(\mathrm{y})$ & $26.22 \pm 5.09$ & $31.67 \pm 10.39$ & 0.16 \\
Weight $(\mathrm{kg})$ & $86.39 \pm 15.42$ & $89.04 \pm 11.73$ & 0.68 \\
BMI $\left(\mathrm{kg} / \mathrm{m}^{2}\right)$ & $26.97 \pm 1.86$ & $26.66 \pm 2.04$ & 0.73 \\
Lean mass $(\%)$ & $88.88 \pm 2.66$ & $88.38 \pm 3.06$ & 0.71 \\
\hline
\end{tabular}

All values are means \pm SD. KD, ketogenic diet group; WD, western diet group.

\subsection{Measurements}

Subjects underwent blood sampling after an overnight fast for blood glucose, insulin, total cholesterol, HDL cholesterol, LDL cholesterol, triglycerides, aspartate transaminase (AST), alanine amino transferase (ALT), total testosterone, insulin growth factor 1 (IGF1), brain-derived neurotrophic factor (BDNF), interleukin-1 (IL-1); interleukin-6 (IL-6) and tumor growth factor (TNF- $\alpha$ ). All the analysis was performed by an accredited and certified laboratory.

Body composition assessment was performed by Bioelectrical Impendence Analysis (Akern mod. STA/BIA 101/S, Pontassieve, FI, Italy). Subjects were asked to lie down and rest for about three-five min in order to allow a balanced redistribution of body fluids. Four skin electrodes were then applied, one on the back of the hand, one on the metacarpal-phalangeal joint of the third finger, one on the dorsum of the ipsilateral foot at the metatarsal-phalangeal joint of the third finger and one on the ankle joint. Using dedicated analysis software (Akern, Body Pro, Pontassieve, Italy) we obtained the values of lean mass (FFM) and fat mass (FM).

Basal metabolism (REE) and respiratory quotient (RER) were measured via indirect calorimetry. Before each procedure, the respiratory gas analyzer (Max Encore 29 System, Vmax, Viasys Healthcare, Inc., Yorba Linda, CA, USA) was calibrated using a special syringe. During the test, participants lay on a cot in a room that was not too bright, quiet and with a temperature of about $24^{\circ} \mathrm{C}$. During the test, participants were asked to breathe regularly in a silicone mask that allowed the analysis of respiratory gases. Data was collected for $30 \mathrm{~min}$, however, only the last $20 \mathrm{~min}$ were taken into account for data analysis. REE was calculated starting from oxygen consumption $\left(\mathrm{VO}_{2}\right)$, based on the Weir equation, while RER was derived from the ratio between the production of $\mathrm{VO}_{2}$ and carbon dioxide $\left(\mathrm{VCO}_{2}\right)$.

Muscle strength was assessed during the second visit. 1-RM test was performed during the squat exercise for the lower limbs' strength, and during the bench press exercise, for the pectorals as previously described [35].

Subjects were requested to refrain from any physical exercise other than normal activities of daily living for at least $48 \mathrm{~h}$ prior to testing. Repetition maximum testing was performed according to the guidelines of the National Strength and Conditioning Association [36]. Briefly, subjects performed a general warm-up prior to testing, followed by a specific warm-up set for each exercise consisting of 5 repetitions at $50 \%$ of an estimated 1-RM followed by one to two sets of 2-3 repetitions at a load corresponding to $60-80 \%$ of 1-RM. Subjects were then asked to gradually reach the load with which they could perform a maximum of one repetition while maintaining the correct realization of the movement: for the bench press the barbell had to touch the chest and return to full arm extension at each repetition without bouncing, and during the squat each movement had to be completed with thighs parallel to the floor

\subsection{Diet Protocols}

The diet was formulated by a dietary team on the basis of the food interview that took place during the first screening visit and in consideration of the specific caloric energy and macronutrient needs for body-building athletes [37] using software for the elaboration of diets (Dieta Ragionata 7.0). 
The two diet regimens were isocaloric and included the same amount of protein per $\mathrm{kg}$ of body weight. The caloric intake of the dietary patterns provided was calculated by assigning an energy expenditure of $45 \mathrm{kcal} / \mathrm{kg}$ of muscle mass, while the protein intake was maintained at $2.5 \mathrm{~g} / \mathrm{kg} /$ body weight as suggested by Apong in 2019 [37]. The two protocols differed in the distribution of fats and carbohydrates; the latter were kept below $5 \%$ daily (less than $50 \mathrm{~g} /$ day) in the KD group while they represented $55 \%$ of the caloric intake in the WD group. The caloric and macronutrient distribution are shown in Table 2. Bodybuilders are known to slavishly follow prescribed diets, normally composed of a restricted and repetitive food regimen $[23,38,39]$. This condition helped to guarantee the adherence to the prescribed diet in both groups throughout the study. Moreover, blood $\mathrm{BHB}$ was regularly checked to avoid exit from ketosis in the KD group.

Table 2. Diet composition and macronutrients distribution.

\begin{tabular}{ccc}
\hline & KD $(\boldsymbol{n}=\mathbf{9})$ & WD $(\boldsymbol{n}=\mathbf{1 0})$ \\
\hline Total Energy intake (kcal/day) & $3443.70 \pm 545.94$ & $3529.71 \pm 374.06$ \\
Protein (kcal) & $863.89 \pm 154.19$ & $890.40 \pm 117.30$ \\
Carbohydrates (kcal) & $175.00 \pm 28.17$ & $1952.50 \pm 209.43^{*}$ \\
Fat (kcal) & $2379.81 \pm 393.78$ & $707.10 \pm 63.66^{*}$ \\
Protein $(\mathrm{g})$ & $215.97 \pm 38.55$ & $222.60 \pm 29.33$ \\
Carbohydrates $(\mathrm{g})$ & $43.75 \pm 7.04$ & $488.13 \pm 52.36^{*}$ \\
Fat (g) & $264.42 \pm 43.75$ & $78.57 \pm 7.07 *$ \\
Protein $(\%)$ & $24.65 \pm 1.24$ & $25.03 \pm 0.91$ \\
Carbohydrates $(\%)$ & $5.00 \pm 0.00$ & $55.00 \pm 0.00^{*}$ \\
Fat $(\%)$ & $68.00 \pm 2.27$ & $19.97 \pm 0.91 *$
\end{tabular}

All values are means \pm SD. * significantly different from KD group $(p<0.05) . \mathrm{KD}$, ketogenic diet group; WD, western diet group.

\subsection{Statistical Analysis}

Data analysis was performed using GraphPad Prism software version 8.4.3 (GraphPad Software, San Diego, CA, USA). Sample size was obtained assuming within subject variability of $30 \%$ and a fixed power of 0.8 , and an alpha risk of 0.05 for the main variables. The analysis determined that at least eight participants per group were needed to achieve the above parameters. Subjects were randomly allocated in one of the two groups using a using computer generated software.

Results are presented as mean $\pm \mathrm{SD}$. After testing for normal distribution with the Shapiro-Wilk W test, a two-way ANOVA for repeated measures was performed to compare the two types of diet through a "time $\times$ diet" analysis. Whenever significant differences in values were found, the post-hoc Bonferroni test was used to identify specific intragroup differences. The $p$-value was set at 0.05 .

\section{Results}

All the recruited subjects successfully completed the study.

Body composition analysis showed that the ketogenic regimen (KD) decreased body weight by approximately $1 \%$ (from $86.39 \pm 15.42 \mathrm{~kg}$ to $85.51 \pm 13.62 \mathrm{~kg}$ ), while the WD determined an increase in weight of about $2 \%$ (from $89.04 \pm 11.73 \mathrm{~kg}$ to $90.37 \pm 9.91 \mathrm{~kg}$ ). Although these differences were not statistically significant $(p>0.05)$, they induced a significant change in body composition (Figure 2). Fat mass significantly decreased only in the KD group (KD: $9.86 \pm 3.79 \mathrm{~kg}$ to $8.42 \pm 2.41 \mathrm{~kg}, p<0.05 \mathrm{vs}$. WD: $10.60 \pm 3.92 \mathrm{~kg}$ to $9.70 \pm 2.53 \mathrm{~kg}$ ) whereas, lean mass significantly increased only in the WD group (KD: from $76.53 \pm 12.13 \mathrm{~kg}$ to $77.09 \pm 11.47 \mathrm{~kg}$ vs. WD: from $78.44 \pm 8.31 \mathrm{~kg}$ to $80.67 \pm 7.72 \mathrm{~kg}$, $p<0.05)$ presenting a significant time $\times$ diet interaction $(p=0.015)$. In terms of the fat mass and lean mass distribution, it was observed that both groups reduced fat mass (KD: $-11.32 \pm 7.88 \%$ vs. WD: $-6.70 \pm 10.02 \%)$, but the difference was statistically significant only in KD group $(p<0.05)$. The decrease in the percentage of fat mass in the KD group 
was associated with a significant increase in lean mass (KD: $+1.63 \pm 1.49 \% ; p=0.01$ vs. WD: $+1.20 \pm 1.62 \% ; p=0.05)$.

A

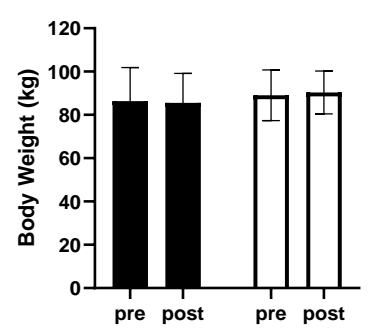

B

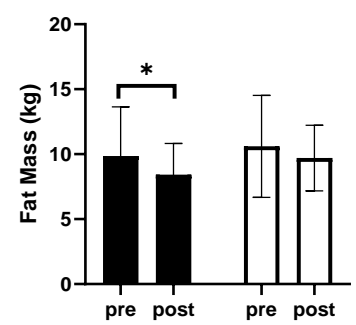

C

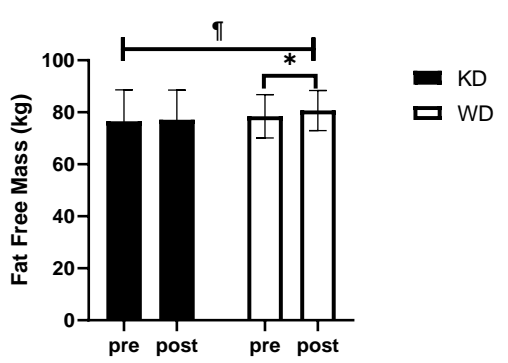

Figure 2. Body composition results after 8 weeks of diet. (A) body weight; (B) Fat Mass; (C) Fat Free Mass. * significantly different from pre-value $(p<0.05)$; II time $\times$ diet interaction $(p<0.05)$. KD, ketogenic diet group; WD, western diet group.

Strength was increased in both study groups, both in the bench press test and in squat test. There were no significant differences between study groups. As shown in Table 3, the KD group improved their performance in bench press and squats by $4.13 \%$ and $3.62 \%$; while the WD group improved by $3.75 \%$ and $6.40 \%$, respectively.

Table 3. Muscle strength and basal metabolism results.

\begin{tabular}{|c|c|c|c|c|c|c|c|}
\hline & \multicolumn{2}{|c|}{$\mathrm{KD}(n=9)$} & \multicolumn{2}{|c|}{$\mathrm{WD}(n=10)$} & \multirow{2}{*}{$\begin{array}{c}\text { Diet } \\
p \text {-Value }\end{array}$} & \multirow{2}{*}{$\begin{array}{c}\text { Time } \\
p \text {-Value }\end{array}$} & \multirow{2}{*}{$\begin{array}{c}\text { Time } \times \text { Diet } \\
p \text {-Value }\end{array}$} \\
\hline & Pre & Post & Pre & Post & & & \\
\hline Bench press $1 \mathrm{RM}(\mathrm{kg})$ & $129.78 \pm 20.98$ & $134.44 \pm 17.14$ * & $136.40 \pm 11.27$ & $141.40 \pm 10.24$ * & ns & 0.0009 & ns \\
\hline Squat $1 \mathrm{RM}(\mathrm{kg})$ & $181.33 \pm 36.52$ & $187.78 \pm 37.41 *$ & $176.10 \pm 27.87$ & $187.00 \pm 26.96^{*}$ & ns & $<0.0001$ & ns \\
\hline $\begin{array}{l}\text { Basal metabolism (REE) } \\
\text { (Kcal/day) }\end{array}$ & $2014.67 \pm 324.04$ & $2052.56 \pm 317.99$ & $2069.10 \pm 229.32$ & $2125.20 \pm 206.08^{*}$ & ns & 0.0006 & ns \\
\hline $\begin{array}{l}\text { Respiratory exchange } \\
\text { ratio (RER) }\end{array}$ & $0.82 \pm 0.01$ & $0.79 \pm 0.02 *$ & $0.83 \pm 0.01$ & $0.83 \pm 0.02 \#$ & 0.0022 & 0.0002 & 0.0001 \\
\hline
\end{tabular}

All values are means \pm SD. ${ }^{*}$ significantly different from pre value $(p<0.05)$; \# significantly different from $\mathrm{KD}$ group $(p<0.05)$. KD, ketogenic diet group; WD, western diet group.

Analysis by indirect calorimetry (Table 3) showed a significant increase in REE only in the WD group (WD: $+2.85 \pm 1.78 \% ; p<0.05$ vs. KD: $+1.99 \pm 3.04 \%$ ). RER revealed a significant time $\times$ diet interaction $(p<0.0001)$ with a significant decrease only in the KD group $(-3.77 \pm 1.86 \% p=0.02)$, whilst in the WD group it remained unchanged.

Blood analyses revealed an improvement in the lipid profile only in the KD group (Table 4). Indeed, total cholesterol significantly decreased in the KD group (KD: $-3.51 \pm 3.72 \%$, $p<0.05$ vs. WD: $-1.59 \pm 3.51 \%)$ and the HDL component exhibited a significant time $\times$ diet interaction $(p=0.004)$, with an increase in the KD group $(4.93 \pm 3.53 \%, p<0.05$ vs. WD: $-1.07 \pm 4.46 \%$ ) and the difference between groups after eight weeks of intervention was statistically different. Triglycerides also presented a significant time $\times$ diet interaction $(p<0.001)$, in which lipids significantly decreased in the KD group $(-17.44 \pm 7.16 \%$; $p<0.0001)$ but not in the WD group $(-1.59 \pm 5.50 \%)$. 
Table 4. Blood parameters.

\begin{tabular}{|c|c|c|c|c|c|c|c|}
\hline & \multicolumn{2}{|c|}{$\mathrm{KD}(n=9)$} & \multicolumn{2}{|c|}{$\mathrm{WD}(n=10)$} & \multirow{2}{*}{$\begin{array}{c}\text { Diet } \\
p \text {-Value }\end{array}$} & \multirow{2}{*}{$\begin{array}{c}\text { Time } \\
p \text {-Value }\end{array}$} & \multirow{2}{*}{$\begin{array}{c}\text { Time } \times \text { Diet } \\
p \text {-Value }\end{array}$} \\
\hline & Pre & Post & Pre & Post & & & \\
\hline \multicolumn{8}{|l|}{ Lipid profile } \\
\hline Total Cholesterol (mg/dL) & $194.78 \pm 8.88$ & $187.89 \pm 10.15 *$ & $193.90 \pm 18.18$ & $190.60 \pm 16.73$ & ns & 0.0071 & ns \\
\hline HDL $(\mathrm{mg} / \mathrm{dL})$ & $57.22 \pm 3.33$ & $60.00 \pm 3.33 *$ & $52.50 \pm 6.11$ & $51.80 \pm 5.05 \#$ & 0.0072 & ns & 0.0039 \\
\hline $\mathrm{LDL}(\mathrm{mg} / \mathrm{dL})$ & $113.33 \pm 8.88$ & $108.00 \pm 10.28$ & $118.60 \pm 20.64$ & $116.20 \pm 18.39$ & ns & ns & ns \\
\hline $\mathrm{TG}(\mathrm{mg} / \mathrm{dL})$ & $121.00 \pm 26.70$ & $99.22 \pm 19.72 *$ & $114.70 \pm 13.21$ & $112.70 \pm 13.06$ & ns & $<0.0001$ & 0.0003 \\
\hline \multicolumn{8}{|l|}{ Transaminase } \\
\hline Aspartate transaminase (AST) (mg/dL) & $38.78 \pm 2.82$ & $38.44 \pm 2.54$ & $39.10 \pm 3.67$ & $39.30 \pm 4.11$ & ns & ns & $\mathrm{ns}$ \\
\hline Alanine amino transferase (ALT) $(\mathrm{mg} / \mathrm{dL})$ & $43.11 \pm 6.51$ & $38.56 \pm 3.30 *$ & $42.10 \pm 6.59$ & $44.80 \pm 5.92$ & ns & ns & 0.0086 \\
\hline \multicolumn{8}{|l|}{ Anabolic Hormones } \\
\hline Testosterone total (nmol/L) & $21.76 \pm 5.33$ & $19.32 \pm 4.09 *$ & $20.96 \pm 5.13$ & $21.27 \pm 4.91$ & ns & 0.0094 & 0.0016 \\
\hline IGF-1 (ng/mL) & $213.33 \pm 39.41$ & $181.50 \pm 25.93 *$ & $222.40 \pm 34.27$ & $219.80 \pm 23.42 \#$ & ns & 0.0050 & 0.0124 \\
\hline
\end{tabular}

All values are means $\pm \mathrm{SD}$. ${ }^{*}$ significantly different from pre value $(p<0.05)$; \# significantly different from KD group $(p<0.05)$ KD, ketogenic diet group; WD, western diet group.

Similarly to what was seen for HDL cholesterol, glucose and insulin concentrations also significantly decreased only in the KD group at the end of the eight weeks of treatment (Figure 3). Plasma glucose levels were reduced from $98.67 \pm 6.68 \mathrm{mg} / \mathrm{dL}$ to $92.22 \pm 4.76 \mathrm{mg} / \mathrm{dL}$ in the KD group $(p<0.001)$, and from $101.20 \pm 3.12 \mathrm{mg} / \mathrm{dL}$ at $99.30 \pm 4.76 \mathrm{mg} / \mathrm{dL}$ in the WD group. Insulinemia decreased from $2.40 \pm 1.81 \mu \mathrm{U} / \mathrm{mL}$ to $1.81 \pm 0.31 \mu \mathrm{U} / \mathrm{mL}$ in the KD group $(p<0.0001)$ while in the WD group it went from $2.42 \pm 0.39 \mu \mathrm{U} / \mathrm{mL}$ to $2.34 \pm 0.33 \mu \mathrm{U} / \mathrm{mL}$.

A

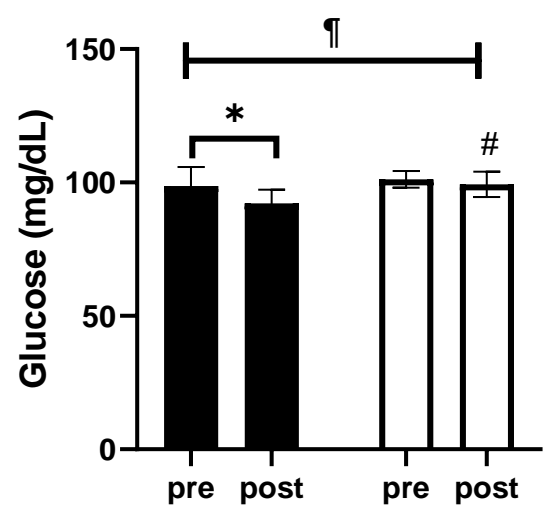

B

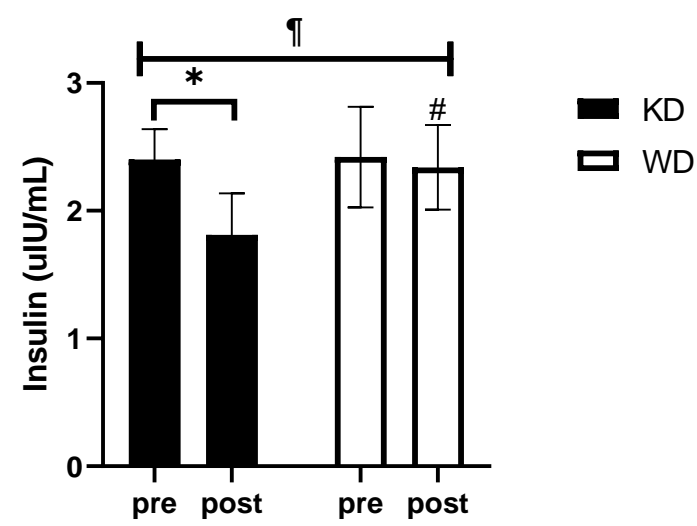

Figure 3. Insulin sensitivity results. (A) plasma glucose concentration; (B) plasma insulin concentration. * significantly different from pre-value $(p<0.05)$; \# significantly different from KD group $(p<0.05)$; II time $\times$ diet interaction $(p<0.05)$. $\mathrm{KD}$, ketogenic diet group; WD, western diet group.

Transaminase analysis (Table 4) showed no difference for aspartate transaminase (AST), while a significant time $\times$ diet interaction $(p<0.01)$ was observed in alanine amino transferase (ALT), whose concentrations decreased significantly only in the KD group $(p<0.05)$ but not in the WD group.

As regards hormone levels, the trend already observed in other studies was confirmed, in that anabolic hormones, such as testosterone and IGF-1 (Table 4), decreased in KD group. A significant time $\times$ diet interaction was observed $(p<0.05)$, resulting in a significant decrease in the KD group (total testosterone $-10.22 \pm 6.95 \%, p<0.001$; IGF-1 $-16.43 \pm 8.52 \%$, $p<0.05$ ) but not in the WD (testosterone total from $-2.01 \pm 5.45 \%$; IGF-1 $-0.18 \pm 9.48 \%$ ).

The analysis of inflammatory markers did not reveal any changes in IL-1 (KD: from $0.92 \pm 0.14 \mathrm{pg} / \mathrm{mL}$ to $0.87 \pm 0.10 \mathrm{pg} / \mathrm{mL}$; WD: from $0.93 \pm 0.10 \mathrm{pg} / \mathrm{mL}$ to $0.96 \pm 0.08 \mathrm{pg} / \mathrm{mL}$ ), while a significant time $\times$ diet interaction $(p<0.05)$ emerged for IL-6 and TNF- $\alpha$ (Figure 4). The IL-6 presented an opposite trend in the two groups; in fact it decreased in the KD group 
by $13.35 \%$ and increased in the WD group by $6.52 \%$, resulting in a statistically significant difference between the two groups at the end of the study protocol (KD: $1.17 \pm 0.30 \mathrm{pg} / \mathrm{mL}$ vs. WD: $1.55 \pm 0.39 \mathrm{pg} / \mathrm{mL} ; p<0.05)$. TNF- $\alpha$, on the other hand, remained almost unchanged in the WD (from $5.33 \pm 0.64 \mathrm{pg} / \mathrm{mL}$ to $5.30 \pm 0.58 \mathrm{pg} / \mathrm{mL}$ ), while it significantly decreased in the KD group (from $5.12 \pm 0.61 \mathrm{pg} / \mathrm{mL}$ to $4.69 \pm 0.38 \mathrm{pg} / \mathrm{mL} ; p<0.01$ ).

A

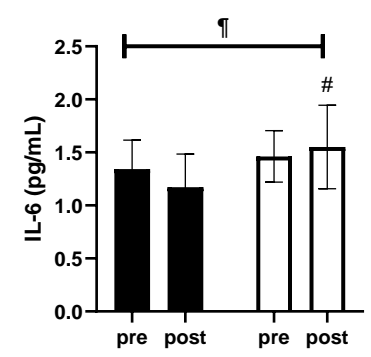

B

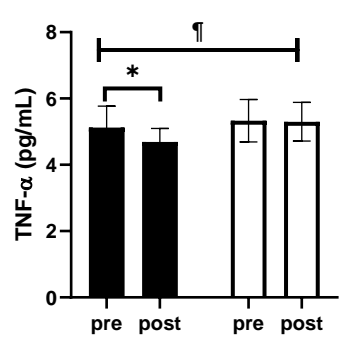

C

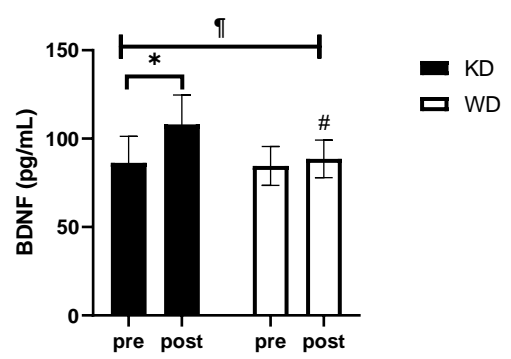

Figure 4. Inflammatory markers and brain-derived neurotrophic factor (BDNF). (A) IL-6 concentration; (B) TNF- $\alpha$ concentration; (C) BDNF concentration. * significantly different from pre-value $(p<0.05)$; \# significantly different from KD group $(p<0.05)$; II time $\times$ diet interaction $(p<0.05)$. KD, ketogenic diet group; WD, western diet group.

Finally, BDNF concentrations (Figure 4) significantly increased only in the KD group $(+25.84 \pm 11.01 \% ; p<0.0001)$ at the end of the eight weeks of treatment (KD: $108.00 \pm$ $15.68 \mathrm{pg} / \mathrm{mL}$ vs. WD: $88.60 \pm 10.62 \mathrm{pg} / \mathrm{mL} ; p<0.01)$.

\section{Discussion}

To our knowledge this is the first study analyzing the effects of a KD on bodybuilders. Our findings confirm several preliminary data on the effects of KD diet on different power sports. KD induced a significant loss of fat mass without affecting muscle performance. Interestingly, fat free mass was maintained throughout the two months of KD despite a significant reduction in blood anabolic hormone concentrations. Moreover, blood lipids, glucose and inflammatory markers were improved in the KD group.

While the effects of KD on fat mass are consistent in all studies evaluating body composition during KD regimens on athletes $[13,20,40]$, the same was not confirmed for lean mass, with some authors showing a catabolic effect of KD on muscle [19,41-43], others showing no direct effects $[13,44]$. Only one study showed a higher increase in lean body mass that was measured after one week of carbohydrate recharge [45]. Muscle mass accrual is obtained under a chronic stimulation of muscle protein synthesis, which is governed by hormonal (IGF-1, testosterone) and transcriptional regulatory pathway (Akt/mTOR). During KD, the reduction in carbohydrates intake leads to a decrease in insulin levels [46]. Insulin is the main regulator of glucose uptake and is regulate by plasma glucose level; as such, lower level of blood glucose caused by the reduction of carbohydrates ingestion, inhibit $\beta$-cells insulin secretion [9]. Insulin is also a potent anabolic hormone [47], and a reduction in insulin levels facilitates mobilization from fat stores due to its effects on lipo-synthesis/lipolysis balance; on the other hand, it may inhibit muscle growth pathway. On a transcriptional level, KD seems to be able to increase the phosphorylation of the AMP-activated protein kinase (AMPK) [48], which has a well-known effect on Akt/mTOR pathway's inhibition [30]. In the present study we were not able to examine the effect of KD on a molecular level, but we observed, as expected, a significant decrease in insulin concentrations, which may play a role in body fat utilization [49]. We also observed an unexpected decrease in testosterone concentration. Most of the studies conducted so far showed a negligible effect of KD on testosterone [50,51], whilst our results showed a drop of $\sim 11 \%$, accompanied by a significant decrease in IGF-1 ( 15\%). Taken together, the anabolic hormonal response seems to be blunted during the KD regimen, and this may explain the attenuated hypertrophic response that was observed. However, in contrast with the studies that showed a decrease in lean body mass during KD, we observed a preservation 
of FFM; this is most likely due to the effect of resistance training stimuli and also to the maintenance of an high dietary protein level (2.5 g/BW) [13,14,17,52].

If a low carbohydrate intake has affected muscle gain, it did not alter muscle performance. Strength and power athletes are recommended to maintain a higher carbohydrate intake (3-8 g/ kg) [53-55] to sustain the intramuscular glycogen stores and engage in greater training volume. It has been observed that during KD regimen muscle glycogen stores can decrease by $\sim 40-50 \%$ [56,57]. In a recent study from Chappell et al. [23], the authors observed that bodybuilders with better results during the competition season normally consumed a greater amount of carbohydrates $(5.1 \mathrm{~g} / \mathrm{kg})$ compared to non-placed athletes. Recently, Vargas-Molina et al., while confirming the maintenance of lean body mass during $\mathrm{KD}$ in strength trained women, found a decrease of strength in bench press and squat exercises [20]. On the contrary, despite the above cited guidelines, we [13] and others [58] observed similar improvement in strength expression after KD compared to normal diet groups. Although further studies are required to better explore this aspect, the majority of studies seem to indicate that KD does not impact muscle performance.

Variations in the basal metabolic rate and respiratory quotient parameters confirm the ability of KD to lower the RER, indicating a shift towards lipid metabolism. Lower RER value seems to predict a better ability to handle future body weight $[59,60]$; this could be an advantage for bodybuilders, who normally undergo to repetitive cycle of bulking and cutting during their carrier. Moreover, REE did not change in the KD group while it was slightly increased in the WD group, suggesting that KD does not negatively affect basal metabolism. The preservation of lean mass observed in the present study certainly contributed to the control of basal metabolism [61]. Additionally, these results suggest that an improvement in resting nutrient oxidation could be one of the main mechanisms by which KD reduces body fat even though the energy intake was similar in the two groups. There is still a debate about the mechanisms underlying the demonstrated greater effects of KD on weight loss in ecological studies. There are some studies pointing out that that the fat loss induced by a ketogenic diet relies only on calorie deficit [62] whilst others suggested that KD induces an increase in REE $[52,63]$. No significant differences in energy intake between groups were detected in our study. Thus, a possible explanation of the greater fat loss in the KD may rely on increased (not measured in our study) spontaneous physical activity during the daily normal activities as suggested by Hall et al. [64].

Bodybuilders' training regimen, which unfortunately is sometimes accompanied with the use of self-administrated steroids, may increase LDL concentration, and reduce HDL levels, increasing the risk of cardiovascular diseases $[65,66]$. In this context, KD may represent a useful tool to control lipid markers. The improvement in lipid profile with KD is well documented in obese and overweight subjects $[67,68]$, whilst the results are still contradictory in athletes, probably due to the difference in the type of training (aerobic or anaerobic activities) adopted in the study design $[19,69]$. We observed an improvement of TGs, HDL and LDL cholesterol blood concentrations. KD can directly influence endogenous cholesterol synthesis via the reduction of insulin production: insulin is indeed one of the major activators of the HMGCoA reductase, the key enzyme of cholesterol biosynthesis. The concomitant reduction in carbohydrates intake and increase in dietary cholesterol (derived from fat intake) results in a consequent inhibition of endogenous cholesterol production [70]. Moreover, during KD, dietary triglycerides are rapidly metabolized to release glycerol, which can be used in the liver for energy purposes [71].

KD effect on insulin and glycemic control deserves mention. Several researches have demonstrated that KD can reduce glucose and insulin concentration in obese, insulin resistant individuals and diabetics [72-75]. This effect is not only related to a reduced intake of glucose within the diet, but also to the improvement in insulin sensitivity [12]. In the present study, despite the healthy status of the participants, KD induced a significant drop in blood glucose which remained within normal levels. We also observed a significant reduction in ALT levels. ALT is not only a hepatic enzyme (although non-specific) but it is a critical enzyme for energy homeostasis. During fasting or sustained exercise, glucose can 
be synthetized from glucogenic amino acids, such as alanine and glutamate. Specifically, ALT can convert alanine into pyruvate to generate glucose via gluconeogenesis [76]. In obese and diabetic patient, elevated ALT activity has been associated with an impaired insulin sensitivity $[77,78]$ suggesting that ALT may play a pivotal role in the pathogenesis of insulin resistance. The reduced ALT levels observed in the KD group may suggest that the use of ketone bodies as an energy source is optimized to reduce the need for amino acids for glucogenic purposes; on the other hand, these results also seem to confirm the improvement in insulin sensitivity, and consequently a reduced risk of developing diabetes or insulin resistance.

Another extremely interesting outcome is the inflammatory response. IL- $1 \beta$ remain unaltered, whilst TNF- $\alpha$ and IL- 6 decreased during KD. These cytokines are linked to oxidative stress or inflammation; thus, their reduction could indicate an attenuation of basal inflammatory status. Furthermore, TNF- $\alpha$ and IL- 6 concentrations are generally related to insulin levels; in fact, these cytokines play an important role in the pathogenesis of insulin resistance [60-63]. Intense protocols of resistance training induce muscle damage, which promote an acute inflammatory response and eventually generates oxygen free radicals and lipid peroxidation $[64,65]$. If the acute rise in IL-6 could be related to training and is indeed a fundamental factor in adapting to exercise stimuli, chronic elevated levels of IL-6 can interact with the STAT3/TLR-4 pathway and decrease insulin sensitivity and display an additional deleterious effect. KD seems to be a useful tool to modulate the inflammatory response, reducing the basal level of proinflammatory cytokines.

Finally, we observed an increase in BDNF blood concentration during KD. BDNF is a molecule of the neurotrophin family involved in trophism and neuronal plasticity, but also in the energy modulation and glucose homeostasis of the central nervous system [79]. A reduction in this protein can be associated with situations of stress, depression, mood disorders, cognitive aspects and other psychological problems [29,30]. An animal model of depression presented reduced level of BDNF [80], and when administrated BDNF seems to display antidepressant effect [81]. Some research has revealed that during weight loss programs subjects may experience depression and negative feelings [28]. However, in humans, KD has been shown to raise BDNF levels, probably via BHB regulation [82], which was also associated with substantial improvement in cognitive function [83]. BHB regulates BDNF expression in the mouse brain by a mechanism similar to the one induced by exercise. Indeed, physical exercise increases BHB levels and BDNF expression in the hippocampus [84]. BDNF expression is increased after an intraventricular infusion of BHB [85]; thus, the increased level of blood BHB reached during a ketogenic diet $[9,86]$ may explain the increased BDNF in the KD group. We have already observed no negative mood variations during KD [87] and an increased BDNF level may explain this observation; moreover, a higher level of BDNF may improve cognition and memory, important factors in athletes.

\section{Limitations}

One of the limitations of this study was the impossibility of standardizing training. Participants were all experienced athletes with many years of training experience; all performed from three to four sessions per week, but the volume and the intensity of the workouts were decided by each individual. The competitive season always takes place around the same time of the year, and the athletes were recruited and started the study in the same period. Therefore, given that the study was conducted for all subjects at the same time of the year (off-season), the training program was similar for participants and aimed at improving muscle mass $[21,88,89]$. We should also point out that this research studied expert bodybuilders, and thus not all the results may be generalized to other sports or the general population. 


\section{Conclusions}

The results show that a KD diet may represent an adequate dietary approach for BB athletes. Despite the lack of hypertrophic response in the KD group, muscle mass was maintained, a phenomenon that often does not occur during low-calorie diets. Similarly, although the time of year was not the one that athletes usually dedicate to training for fat loss ("cutting"), KD proved to be a good strategy to reduce body fat.

$\mathrm{KD}$ also resulted in a decrease in inflammatory cytokines and the increase in BDNF, suggesting that KD can be a valid tool for dealing with moments (such as that of "weightlifting") where stress management and maintenance of motivation are hard to handle. KD is not a regime to be followed lightly and independently but requires the presence of a professional; in these circumstances KD represents a fundamental tool in the nutritionist's baggage to face various conditions and needs, including those of sports.

Author Contributions: Conceptualization, A.P.; formal analysis, T.M.; data curation, A.P. and T.M.; writing—original draft preparation, T.M. and M.N.; writing—review and editing, A.P., L.C., P.P., N.S., A.B., M.N., M.C. and T.M.; supervision, A.P.; All authors have read and agreed to the published version of the manuscript.

Funding: This research received no external funding.

Institutional Review Board Statement: The study was conducted according to the guidelines of the Declaration of Helsinki, and approved by the the ethical committee of the Department of Biomedical Sciences, University of Padova (HEC-DSB 11/19, 2019).

Informed Consent Statement: Informed consent was obtained from all subjects involved in the study.

Data Availability Statement: Data available on request from the authors.

Conflicts of Interest: The authors declare no conflict of interest.

\section{References}

1. Muscogiuri, G.; Barrea, L.; Laudisio, D.; Pugliese, G.; Salzano, C.; Savastano, S.; Colao, A. The management of very low-calorie ketogenic diet in obesity outpatient clinic: A practical guide. J. Transl. Med. 2019, 17, 356. [CrossRef]

2. Paoli, A. Ketogenic diet for obesity: Friend or foe? Int. J. Environ. Res. Public Health 2014, 11, 2092-2107. [CrossRef] [PubMed]

3. Paoli, A.; Bianco, A.; Grimaldi, K.A. The Ketogenic Diet and Sport: A Possible Marriage? Exerc. Sport Sci. Rev. 2015, 43, 153-162. [CrossRef] [PubMed]

4. Società Italiana di Nutrizione Umana (S.I.N.U.). Livelli di Assunzione Raccomandati di Energia e Nutrienti per la Popolazione Italiana, LARN-Revisione 2014. Available online: http:/ / www.sinu.it (accessed on 1 December 2020).

5. Paoli, A.; Cenci, L.; Fancelli, M.; Parmagnani, A.; Fratter, A.; Cucchi, A.; Bianco, A. Ketogenic diet and phytoextracts. Comparison of the efficacy of Mediterranean, zone and tisanoreica diet on some health risk factors. Agro Food Ind. Hi-Tech 2010, $21,24-29$.

6. Rubini, A.; Bosco, G.; Lodi, A.; Cenci, L.; Parmagnani, A.; Grimaldi, K.; Zhongjin, Y.; Paoli, A. Effects of Twenty Days of the Ketogenic Diet on Metabolic and Respiratory Parameters in Healthy Subjects. Lung 2015, 193, 939-945. [CrossRef] [PubMed]

7. McPherson, P.A.; McEneny, J. The biochemistry of ketogenesis and its role in weight management, neurological disease and oxidative stress. J. Physiol. Biochem. 2012, 68, 141-151. [CrossRef]

8. Owen, O.E.; Felig, P.; Morgan, A.P.; Wahren, J.; Cahill, G.F., Jr. Liver and kidney metabolism during prolonged starvation. J. Clin. Investig. 1969, 48, 574-583. [CrossRef] [PubMed]

9. Nelson, D.L.; Cox, M.M. Lehninger principles of biochemistry. Worth Publ. 2000, 41, 113-158.

10. Fukao, T.; Lopaschuk, G.D.; Mitchell, G.A. Pathways and control of ketone body metabolism: On the fringe of lipid biochemistry. Prostaglandins Leukot. Essent. Fat. Acids 2004, 70, 243-251. [CrossRef]

11. Paoli, A.; Grimaldi, K.; Bianco, A.; Lodi, A.; Cenci, L.; Parmagnani, A. Medium term effects of a ketogenic diet and a Mediterranean diet on resting energy expenditure and respiratory ratio. BMC Proc. 2012, 6, P37. [CrossRef]

12. Paoli, A.; Rubini, A.; Volek, J.S.; Grimaldi, K.A. Beyond weight loss: A review of the therapeutic uses of very-low-carbohydrate (ketogenic) diets. Eur. J. Clin. Nutr. 2013, 67, 789-796. [CrossRef] [PubMed]

13. Paoli, A.; Grimaldi, K.; D’Agostino, D.; Cenci, L.; Moro, T.; Bianco, A.; Palma, A. Ketogenic diet does not affect strength performance in elite artistic gymnasts. J. Int. Soc. Sports Nutr. 2012, 9, 34. [CrossRef] [PubMed]

14. Burke, L.M.; Whitfield, J.; Heikura, I.A.; Ross, M.L.; Tee, N.; Forbes, S.F.; Hall, R.; McKay, A.K.; Wallett, A.M.; Sharma, A.P. Adaptation to a low carbohydrate high fat diet is rapid but impairs endurance exercise metabolism and performance despite enhanced glycogen availability. J. Physiol. 2020. [CrossRef] [PubMed] 
15. Heikura, I.A.; Burke, L.M.; Hawley, J.A.; Ross, M.L.; Garvican-Lewis, L.; Sharma, A.P.; McKay, A.K.; Leckey, J.J.; Welvaert, M.; McCall, L. A short-term ketogenic diet impairs markers of bone health in response to exercise. Front. Endocrinol. 2020, 10, 880. [CrossRef] [PubMed]

16. Whitfield, J.; Burke, L.M.; McKay, A.K.; Heikura, I.A.; Hall, R.; Fensham, N.; Sharma, A.P. Acute Ketogenic Diet and Ketone Ester Supplementation Impairs Race Walk Performance. Med. Sci. Sports Exerc. 2020. [CrossRef] [PubMed]

17. Paoli, A.; Cancellara, P.; Pompei, P.; Moro, T. Ketogenic diet and skeletal muscle hypertrophy: A frenemy relationship? J. Hum. Kinet. 2019, 68, 233-247. [CrossRef] [PubMed]

18. Jabekk, P.T.; Moe, I.A.; Meen, H.D.; Tomten, S.E.; Hostmark, A.T. Resistance training in overweight women on a ketogenic diet conserved lean body mass while reducing body fat. Nutr. Metab. (Lond.) 2010, 7, 17. [CrossRef]

19. Kephart, W.C.; Pledge, C.D.; Roberson, P.A.; Mumford, P.W.; Romero, M.A.; Mobley, C.B.; Martin, J.S.; Young, K.C.; Lowery, R.P.; Wilson, J.M.; et al. The Three-Month Effects of a Ketogenic Diet on Body Composition, Blood Parameters, and Performance Metrics in CrossFit Trainees: A Pilot Study. Sports 2018, 6, 1. [CrossRef]

20. Vargas, S.; Romance, R.; Petro, J.L.; Bonilla, D.A.; Galancho, I.; Espinar, S.; Kreider, R.B.; Benitez-Porres, J. Efficacy of ketogenic diet on body composition during resistance training in trained men: A randomized controlled trial. J. Int. Soc. Sports Nutr. 2018, 15, 31. [CrossRef]

21. Tzur, A.; Roberts, B.M. The ketogenic diet for bodybuilders and physique athletes. Strength Cond. J. 2020, 42, 108-115. [CrossRef]

22. Helms, E.R.; Aragon, A.A.; Fitschen, P.J. Evidence-based recommendations for natural bodybuilding contest preparation: Nutrition and supplementation. J. Int. Soc. Sports Nutr. 2014, 11, 20. [CrossRef] [PubMed]

23. Chappell, A.J.; Simper, T.; Barker, M.E. Nutritional strategies of high level natural bodybuilders during competition preparation. J. Int. Soc. Sports Nutr. 2018, 15, 4. [CrossRef] [PubMed]

24. Gibala, M.J.; MacDougall, J.D.; Tarnopolsky, M.A.; Stauber, W.T.; Elorriaga, A. Changes in human skeletal muscle ultrastructure and force production after acute resistance exercise. J. Appl. Physiol. (1985) 1995, 78, 702-708. [CrossRef] [PubMed]

25. Lindsay, A.; Janmale, T.; Draper, N.; Gieseg, S.P. Measurement of changes in urinary neopterin and total neopterin in body builders using SCX HPLC. Pteridines 2014, 25, 53-63. [CrossRef]

26. Roth, S.M.; Martel, G.F.; Ivey, F.M.; Lemmer, J.T.; Metter, E.J.; Hurley, B.F.; Rogers, M.A. High-volume, heavy-resistance strength training and muscle damage in young and older women. J. Appl. Physiol. (1985) 2000, 88, 1112-1118. [CrossRef] [PubMed]

27. Calle, M.C.; Fernandez, M.L. Effects of resistance training on the inflammatory response. Nutr. Res. Pract. 2010, 4, 259-269. [CrossRef]

28. Fabricatore, A.N.; Wadden, T.A.; Higginbotham, A.J.; Faulconbridge, L.F.; Nguyen, A.M.; Heymsfield, S.B.; Faith, M.S. Intentional weight loss and changes in symptoms of depression: A systematic review and meta-analysis. Int. J. Obes. (Lond.) 2011, 35, 1363-1376. [CrossRef]

29. Altar, C.A. Neurotrophins and depression. Trends Pharmacol. Sci. 1999, 20, 59-61. [CrossRef]

30. Duman, R.S.; Malberg, J.; Nakagawa, S.; D'Sa, C. Neuronal plasticity and survival in mood disorders. Biol. Psychiatry 2000, 48, 732-739. [CrossRef]

31. Paoli, A.; Moro, T.; Bosco, G.; Bianco, A.; Grimaldi, K.A.; Camporesi, E.; Mangar, D. Effects of n-3 polyunsaturated fatty acids (omega-3) supplementation on some cardiovascular risk factors with a ketogenic Mediterranean diet. Mar. Drugs 2015, 13, 996-1009. [CrossRef]

32. Forsythe, C.E.; Phinney, S.D.; Fernandez, M.L.; Quann, E.E.; Wood, R.J.; Bibus, D.M.; Kraemer, W.J.; Feinman, R.D.; Volek, J.S. Comparison of low fat and low carbohydrate diets on circulating fatty acid composition and markers of inflammation. Lipids 2008, 43, 65-77. [CrossRef] [PubMed]

33. Pinto, A.; Bonucci, A.; Maggi, E.; Corsi, M.; Businaro, R. Anti-Oxidant and Anti-Inflammatory Activity of Ketogenic Diet: New Perspectives for Neuroprotection in Alzheimer's Disease. Antioxidants 2018, 7, 63. [CrossRef] [PubMed]

34. Bostock, E.C.; Kirkby, K.C.; Taylor, B.V. The Current Status of the Ketogenic Diet in Psychiatry. Front. Psychiatry 2017, 8, 43. [CrossRef] [PubMed]

35. LeSuer, D.A.; McCormick, J.H.; Mayhew, J.L.; Wasserstein, R.L.; Arnold, M.D. The accuracy of prediction equations for estimating 1-RM performance in the bench press, squat, and deadlift. J. Strength Cond. Res. 1997, 11, 211-213.

36. Baechle, T.R.; Earle, R.W. Essentials of Strength Training and Conditioning; Human Kinetics: Champaign, IL, USA, 2008.

37. Apong, P.E. Nutrition and Dietary Recommendations for Bodybuilders. In Nutrition and Enhanced Sports Performance; Elsevier: Amsterdam, The Netherlands, 2019; pp. 737-750.

38. Rossow, L.M.; Fukuda, D.H.; Fahs, C.A.; Loenneke, J.P.; Stout, J.R. Natural bodybuilding competition preparation and recovery: A 12-month case study. Int. J. Sports Physiol. Perform. 2013, 8, 582-592. [CrossRef]

39. Robinson, S.L.; Lambeth-Mansell, A.; Gillibrand, G.; Smith-Ryan, A.; Bannock, L. A nutrition and conditioning intervention for natural bodybuilding contest preparation: Case study. J. Int. Soc. Sports Nutr. 2015, 12, 20. [CrossRef]

40. Bowler, A.L.; Polman, R. Role of a Ketogenic Diet on Body Composition, Physical Health, Psychosocial Well-Being and Sports Performance in Athletes: A Scoping Review. Sports 2020, 8, 131. [CrossRef]

41. Brinkworth, G.D.; Noakes, M.; Buckley, J.D.; Keogh, J.B.; Clifton, P.M. Long-term effects of a very-low-carbohydrate weight loss diet compared with an isocaloric low-fat diet after 12 mo. Am. J. Clin. Nutr. 2009, 90, 23-32. [CrossRef]

42. Johnstone, A.M.; Horgan, G.W.; Murison, S.D.; Bremner, D.M.; Lobley, G.E. Effects of a high-protein ketogenic diet on hunger, appetite, and weight loss in obese men feeding ad libitum. Am. J. Clin. Nutr. 2008, 87, 44-55. [CrossRef] 
43. Ruth, M.R.; Port, A.M.; Shah, M.; Bourland, A.C.; Istfan, N.W.; Nelson, K.P.; Gokce, N.; Apovian, C.M. Consuming a hypocaloric high fat low carbohydrate diet for 12 weeks lowers C-reactive protein, and raises serum adiponectin and high density lipoproteincholesterol in obese subjects. Metabolism 2013, 62, 1779-1787. [CrossRef]

44. Johnston, C.S.; Tjonn, S.L.; Swan, P.D.; White, A.; Hutchins, H.; Sears, B. Ketogenic low-carbohydrate diets have no metabolic advantage over nonketogenic low-carbohydrate diets. Am. J. Clin. Nutr. 2006, 83, 1055-1061. [CrossRef] [PubMed]

45. Wilson, J.M.; Lowery, R.P.; Roberts, M.D.; Sharp, M.H.; Joy, J.M.; Shields, K.A.; Partl, J.M.; Volek, J.S.; D'Agostino, D.P. Effects of Ketogenic Dieting on Body Composition, Strength, Power, and Hormonal Profiles in Resistance Training Men. J. Strength Cond. Res. 2020, 34, 3463-3474. [CrossRef] [PubMed]

46. McCue, M.D. Starvation physiology: Reviewing the different strategies animals use to survive a common challenge. Comp. Biochem. Physiol. Part A Mol. Integr. Physiol. 2010, 156, 1-18. [CrossRef] [PubMed]

47. Biolo, G.; Fleming, R.D.; Wolfe, R.R. Physiologic hyperinsulinemia stimulates protein synthesis and enhances transport of selected amino acids in human skeletal muscle. J. Clin. Investig. 1995, 95, 811-819. [CrossRef] [PubMed]

48. Kennedy, A.R.; Pissios, P.; Otu, H.; Roberson, R.; Xue, B.; Asakura, K.; Furukawa, N.; Marino, F.E.; Liu, F.F.; Kahn, B.B.; et al. A high-fat, ketogenic diet induces a unique metabolic state in mice. Am. J. Physiol. Endocrinol. Metab. 2007, 292, E1724-E1739. [CrossRef] [PubMed]

49. Campbell, P.J.; Carlson, M.G.; Hill, J.; Nurjhan, N. Regulation of free fatty acid metabolism by insulin in humans: Role of lipolysis and reesterification. Am. J. Physiol. Endocrinol. Metab. 2006, 263, E1063-E1069. [CrossRef]

50. Cangemi, R.; Friedmann, A.J.; Holloszy, J.O.; Fontana, L. Long-term effects of calorie restriction on serum sex-hormone concentrations in men. Aging Cell 2010, 9, 236-242. [CrossRef]

51. Volek, J.S.; Gomez, A.L.; Love, D.M.; Avery, N.G.; Sharman, M.J.; Kraemer, W.J. Effects of a high-fat diet on postabsorptive and postprandial testosterone responses to a fat-rich meal. Metabolism 2001, 50, 1351-1355. [CrossRef]

52. Ludwig, D.S.; Dickinson, S.L.; Henschel, B.; Ebbeling, C.B.; Allison, D.B. Do Lower-Carbohydrate Diets Increase Total Energy Expenditure? An Updated and Reanalyzed Meta-Analysis of 29 Controlled-Feeding Studies. J. Nutr. 2020. [CrossRef]

53. Iraki, J.; Fitschen, P.; Espinar, S.; Helms, E. Nutrition Recommendations for Bodybuilders in the Off-Season: A Narrative Review. Sports 2019, 7, 154. [CrossRef]

54. Roberts, B.M.; Helms, E.R.; Trexler, E.T.; Fitschen, P.J. Nutritional Recommendations for Physique Athletes. J. Hum. Kinet. 2020, 71, 79-108. [CrossRef] [PubMed]

55. Slater, G.; Phillips, S.M. Nutrition guidelines for strength sports: Sprinting, weightlifting, throwing events, and bodybuilding. J. Sports Sci. 2011, 29, S67-S77. [CrossRef] [PubMed]

56. Harber, M.P.; Schenk, S.; Barkan, A.L.; Horowitz, J.F. Alterations in carbohydrate metabolism in response to short-term dietary carbohydrate restriction. Am. J. Physiol. Endocrinol. Metab. 2005, 289, E306-E312. [CrossRef] [PubMed]

57. Phinney, S.D.; Bistrian, B.R.; Evans, W.J.; Gervino, E.; Blackburn, G.L. The human metabolic response to chronic ketosis without caloric restriction: Preservation of submaximal exercise capability with reduced carbohydrate oxidation. Metabolism 1983, 32, 769-776. [CrossRef]

58. Greene, D.A.; Varley, B.J.; Hartwig, T.B.; Chapman, P.; Rigney, M. A low-carbohydrate ketogenic diet reduces body mass without compromising performance in powerlifting and olympic weightlifting athletes. J. Strength Cond. Res. 2018, 32, $3373-3382$. [CrossRef] [PubMed]

59. Seidell, J.C.; Muller, D.C.; Sorkin, J.D.; Andres, R. Fasting respiratory exchange ratio and resting metabolic rate as predictors of weight gain: The Baltimore Longitudinal Study on Aging. Int. J. Obes. Relat. Metab. Disord. 1992, 16, 667-674.

60. Valtuena, S.; Salas-Salvado, J.; Lorda, P.G. The respiratory quotient as a prognostic factor in weight-loss rebound. Int. J. Obes. Relat. Metab. Disord. 1997, 21, 811-817. [CrossRef]

61. Tagliabue, A.; Bertoli, S.; Trentani, C.; Borrelli, P.; Veggiotti, P. Effects of the ketogenic diet on nutritional status, resting energy expenditure, and substrate oxidation in patients with medically refractory epilepsy: A 6-month prospective observational study. Clin. Nutr. 2012, 31, 246-249. [CrossRef]

62. Hall, K.D.; Bemis, T.; Brychta, R.; Chen, K.Y.; Courville, A.; Crayner, E.J.; Goodwin, S.; Guo, J.; Howard, L.; Knuth, N.D. Calorie for calorie, dietary fat restriction results in more body fat loss than carbohydrate restriction in people with obesity. Cell Metab. 2015, 22, 427-436. [CrossRef]

63. Ebbeling, C.B.; Swain, J.F.; Feldman, H.A.; Wong, W.W.; Hachey, D.L.; Garcia-Lago, E.; Ludwig, D.S. Effects of dietary composition on energy expenditure during weight-loss maintenance. JAMA 2012, 307, 2627-2634. [CrossRef]

64. Hall, K.D.; Chen, K.Y.; Guo, J.; Leibel, R.L.; Mayer, L.E.; Reitman, M.L.; Rosenbaum, M.; Smith, S.R.; Walsh, B.T.; Ravussin, E. Raising the bar on the low-carbohydrate diet Reply. Am. J. Clin. Nutr. 2016, 104, 1488-1490. [CrossRef] [PubMed]

65. Hurley, B.F.; Seals, D.R.; Hagberg, J.M.; Goldberg, A.C.; Ostrove, S.M.; Holloszy, J.O.; Wiest, W.G.; Goldberg, A.P. High-densitylipoprotein cholesterol in bodybuilders v powerlifters. Negative effects of androgen use. JAMA 1984, 252, 507-513. [CrossRef] [PubMed]

66. Santora, L.J.; Marin, J.; Vangrow, J.; Minegar, C.; Robinson, M.; Mora, J.; Friede, G. Coronary calcification in body builders using anabolic steroids. Prev. Cardiol. 2006, 9, 198-201. [CrossRef] [PubMed]

67. Dashti, H.M.; Al-Zaid, N.S.; Mathew, T.C.; Al-Mousawi, M.; Talib, H.; Asfar, S.K.; Behbahani, A.I. Long term effects of ketogenic diet in obese subjects with high cholesterol level. Mol. Cell. Biochem. 2006, 286, 1. [CrossRef] [PubMed] 
68. Dashti, H.M.; Mathew, T.C.; Hussein, T.; Asfar, S.K.; Behbahani, A.; Khoursheed, M.A.; Al-Sayer, H.M.; Bo-Abbas, Y.Y.; Al-Zaid, N.S. Long-term effects of a ketogenic diet in obese patients. Exp. Clin. Cardiol. 2004, 9, 200-205.

69. Klement, R.J.; Frobel, T.; Albers, T.; Fikenzer, S.; Prinzhausen, J.; Kämmerer, U. A pilot case study on the impact of a self-prescribed ketogenic diet on biochemical parameters and running performance in healthy and physically active individuals. Nutr. Med. 2013, 1, 10 .

70. Ness, G.C. Regulation of 3-hydroxy-3-methylglutaryl coenzyme A reductase. Mol. Cell. Biochem. 1983, 53, 299-306.

71. Bortz, W.M.; Paul, P.; Haff, A.C.; Holmes, W.L. Glycerol turnover and oxidation in man. J. Clin. Investig. 1972, 51, 1537-1546. [CrossRef]

72. Boden, G.; Sargrad, K.; Homko, C.; Mozzoli, M.; Stein, T.P. Effect of a low-carbohydrate diet on appetite, blood glucose levels, and insulin resistance in obese patients with type 2 diabetes. Ann. Intern. Med. 2005, 142, 403-411. [CrossRef]

73. Lodi, A.; Karsten, B.; Bosco, G.; Gomez-Lopez, M.; Brandao, P.P.; Bianco, A.; Paoli, A. The Effects of Different High-Protein Low-Carbohydrates Proprietary Foods on Blood Sugar in Healthy Subjects. J. Med. Food 2016, 19, 1085-1095. [CrossRef]

74. Paoli, A.; Mancin, L.; Giacona, M.C.; Bianco, A.; Caprio, M. Effects of a ketogenic diet in overweight women with polycystic ovary syndrome. J. Transl. Med. 2020, 18, 104. [CrossRef] [PubMed]

75. Volek, J.S.; Phinney, S.D.; Forsythe, C.E.; Quann, E.E.; Wood, R.J.; Puglisi, M.J.; Kraemer, W.J.; Bibus, D.M.; Fernandez, M.L.; Feinman, R.D. Carbohydrate restriction has a more favorable impact on the metabolic syndrome than a low fat diet. Lipids 2009, 44, 297-309. [CrossRef] [PubMed]

76. Felig, P. The glucose-alanine cycle. Metabolism 1973, 22, 179-207. [CrossRef]

77. Vozarova, B.; Stefan, N.; Lindsay, R.S.; Saremi, A.; Pratley, R.E.; Bogardus, C.; Tataranni, P.A. High alanine aminotransferase is associated with decreased hepatic insulin sensitivity and predicts the development of type 2 diabetes. Diabetes 2002, 51, 1889-1895. [CrossRef] [PubMed]

78. West, J.; Brousil, J.; Gazis, A.; Jackson, L.; Mansell, P.; Bennett, A.; Aithal, G.P. Elevated serum alanine transaminase in patients with type 1 or type 2 diabetes mellitus. QJM Int. J. Med. 2006, 99, 871-876. [CrossRef]

79. Genzer, Y.; Dadon, M.; Burg, C.; Chapnik, N.; Froy, O. Effect of dietary fat and the circadian clock on the expression of brain-derived neurotrophic factor (BDNF). Mol. Cell. Endocrinol. 2016, 430, 49-55. [CrossRef] [PubMed]

80. Smith, M.A.; Makino, S.; Kvetnansky, R.; Post, R.M. Stress and glucocorticoids affect the expression of brain-derived neurotrophic factor and neurotrophin-3 mRNAs in the hippocampus. J. Neurosci. 1995, 15, 1768-1777. [CrossRef] [PubMed]

81. Siuciak, J.A.; Lewis, D.R.; Wiegand, S.J.; Lindsay, R.M. Antidepressant-like effect of brain-derived neurotrophic factor (BDNF). Pharmacol. Biochem. Behav. 1997, 56, 131-137. [CrossRef]

82. Marosi, K.; Kim, S.W.; Moehl, K.; Scheibye-Knudsen, M.; Cheng, A.; Cutler, R.; Camandola, S.; Mattson, M.P. 3-Hydroxybutyrate regulates energy metabolism and induces BDNF expression in cerebral cortical neurons. J. Neurochem. 2016, 139, 769-781. [CrossRef]

83. Mohorko, N.; Černelič-Bizjak, M.; Poklar-Vatovec, T.; Grom, G.; Kenig, S.; Petelin, A.; Jenko-Pražnikar, Z. Weight loss, improved physical performance, cognitive function, eating behavior, and metabolic profile in a 12-week ketogenic diet in obese adults. Nutr. Res. 2019, 62, 64-77. [CrossRef]

84. Murphy, R.M.; Watt, M.J.; Febbraio, M.A. Metabolic communication during exercise. Nat. Metab. 2020, 2, 805-816. [CrossRef] [PubMed]

85. El Hayek, L.; Khalifeh, M.; Zibara, V.; Abi Assaad, R.; Emmanuel, N.; Karnib, N.; El-Ghandour, R.; Nasrallah, P.; Bilen, M.; Ibrahim, P. Lactate mediates the effects of exercise on learning and memory through SIRT1-dependent activation of hippocampal brain-derived neurotrophic factor (BDNF). J. Neurosci. 2019, 39, 2369-2382. [CrossRef] [PubMed]

86. Swink, T.D.; Vining, E.P.; Freeman, J.M. The ketogenic diet: 1997. Adv. Pediatr. 1997, 44, 297-329. [PubMed]

87. Lodi, A.; Zarantonello, L.; Bisiacchi, P.S.; Cenci, L.; Paoli, A. Ketonemia and Glycemia Affect Appetite Levels and Executive Functions in Overweight Females during Two Ketogenic Diets. Obesity (Silver Spring) 2020, 28, 1868-1877. [CrossRef] [PubMed]

88. Helms, E.R.; Fitschen, P.J.; Aragon, A.A.; Cronin, J.; Schoenfeld, B.J. Recommendations for natural bodybuilding contest preparation: Resistance and cardiovascular training. J. Sports Med. Phys. Fit. 2015, 55, 164-178.

89. Hackett, D.A.; Johnson, N.A.; Chow, C.-M. Training practices and ergogenic aids used by male bodybuilders. J. Strength Cond. Res. 2013, 27, 1609-1617. [CrossRef] 